\title{
Современная трудовая миграция из Калмыкии и Тувы: экономические, социокультурные и гендерные аспекты
}

\author{
Ноган В. Бадмаева \\ Калмыцкий научный центр РАН, Российская Федерация, \\ Органа Д. Натсак
}

Тувинский институт гуманитарных и прикладных социально-экономических исследований при Правительстве Республики Тыва, Российская Федерация



В статье представлен сравнительный анализ современных миграционных процессов в двух российских регионах - Республике Калмыкия и Республике Тыва. Они имеют близкие социально-экономические характеристики, высокий уровень бедности, что приводит к выталкиванию населения в другие регионы России. При этом современная трудовая миграция в Калмыкии и Туве происходит на фоне разных демографических процессов. В Калмыкии это депопуляционные процессы, а в Туве - рост численности населения.

Проанализированы разные этапы миграционного движения населения Калмыкии и Тувы, начиная от принятия решения о трудовой миграции, выбора направления, каналов поиска работы до «приживаемости» - адаптации к особенностям климатических, бытовых и социокультурных условий, удовлетворенности уровнем зарплаты в регионе пребывания, а также дальнейшие жизненные стратегии, связанные со сроками трудовой миграции, перспективами возвращения. Особое внимание было уделено вопросам сохранения этнической, религиозной идентичности в иноэтнической среде, связям с малой родиной, а также гендерным аспектам трудовой миграции.

Источниковой базой исследования стали статические данные, а также материалы

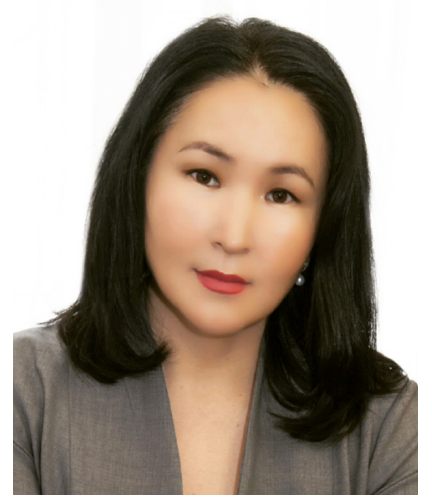
глубинных интервью в 2021 г. с 43 респондентами - участниками межрегиональной трудовой миграции. Для респондентов из Тувы основной причиной миграции является стратегия оплаты кредитных задолженностей, необходимость обеспечения детей. Для респондентов из Калмыкии миграция в районы Крайнего Севера является возможностью реализации своего профессионального потенциала, развития карьеры, поскольку это невозможно осуществить на своей малой родине. У трудовых мигрантов сохраняются тесные связи с малой родиной, наблюдается стремление к сохранению этнической $и$ религиозной идентичности, в местах миграции формируются этнические сообщества.

Трудовая миграция во многом имеет возвратный характер, но вместе с тем пролонгирована во времени, что может в перспективе стать источником демографических и кадровых проблем для регионов-доноров, которыми выступают Калмыкия и Тува.

Ключевые слова: миграционный процесс; Калмыкия; Тыва; Тува; калмыки; тувинцы; внутренняя миграция; трудовая миграция; миграционные интенции населения; социокультурная адаптация; трудовой мигрант; гендерный аспект

Исследование проведено в рамках госзадания КалмНЦ РАН «Развитие сельских территорий Юга России: комплексный социально-экономический и экологический мониторинг» (Рег. № НИОКТР АААА-А19-1190111490037-8).

Для цитирования:

Бадмаева Н. В., Натсак О. Д. Современная трудовая миграция из Калмыкии и Тувы: экономические, социокультурные и гендерные аспекты // Новые исследования Тувы. 2021, № 4. С. 186-205. DOI: https://www.doi.org/10.25178/ nit.2021.4.14

Бадмаева Ноган Вячеславовна - научный сотрудник отдела комплексного мониторинга и информационных технологий Калмыцкого научного центра РАН. Адрес: 358000, Россия, г. Элиста, ул. Илишкина, д. 8. Тел.: +7 (84722) 3-55-06. Эл. адрес: badmaevanv@kigiran.com

Натсак Органа Доржуевна - кандидат философских наук, ученый секретарь Тувинского института гуманитарных и прикладных социально-экономических исследований при Правительстве Республики Тыва. Адрес: 667000, Россия, г. Кызыл, ул. Кочетова, д. 4 . Тел.: + 7 (394-22) 2-39-36. Эл. адрес: nod695596@gmail.com 


\title{
Modern labor migration from Kalmykia and Tuva: economic, socio-cultural and gender aspects
}

\author{
Nogan V. Badmaeva \\ Kalmyk Scientific Center of the Russian Academy of Sciences, Russian Federation, \\ Organa D. Natsak \\ Tuvan Institute of Humanities and Applied Social and Economic Research \\ under the Government of the Republic of Tuva, Russian Federation
}

\begin{abstract}
The article presents a comparative analysis of contemporary migration processes in two Russian regions, geographically distant from each other, but having common historical and socio-cultural roots - the Republic of Kalmykia and the Republic of Tuva. They also have similar social and economic performance indicators, and a high level of poverty, all of which tends to push the populations out of both regions. At the same time, the background for labor migration is quite different: while Kalmykia is experiencing depopulation, Tuva's population is growing.

The authors have analyzed different stages of the migration process in Kalmykia and Tuva, ranging from making a decision to move out of the region, choosing a destination and job search channels, to «adaptability» to the peculiarities of climatic, living and sociocultural conditions, satisfaction with the level of wages in the new region of residence, as well as further life strategies, such as timing the move or prospects of returning. Special attention was paid to the issues of preserving ethnic and religious identity in a different ethnic environment, to the surviving ties with home area, as well as to the gender aspects of labor migration.

For its sources, the study relies on statistics, and on the in-depth interviews 43 respondents gave in 2021. All of them moved out of their own regions. The respondents from Tuva found the main reason for their migration in the need to pay off credit arrears and to provide for children. For respondents from Kalmykia, migration to the Far North is an opportunity to realize their professional potential and career development, since it is unattainable in their home republic. In-depth interviews confirm that labor migrants maintain close ties with their home area, express a desire to preserve their ethnic and religious identity, and tend to join or start ethnic communities in places of migration.

To conclude, labor migration, despite its recurrent nature, is becoming a prolonged process, and ay in the future become a source of demographic and personnel problems for donor regions, such as Kalmykia and Tuva.
\end{abstract}

Keywords: migration processes; Republic of Kalmykia; Republic of Tuva; internal migration; labor migration; migration intentions; socio-cultural adaptation; labor migrants; gender aspect

The research was carried out as part of the commission by Kalmyk Scientific Center, RAS "The development of the rural territories in the South of Russia: comprehensive socioeconomical and environmental monitoring”(Re. No. NIOKTR AAAA-A19-1190111490037-8).

\section{For citation:}

Badmaeva N. V. and Natsak O. D. Sovremennaia trudovaia migratsiia iz Kalmykii i Tuvy: ekonomicheskie, sotsiokul'turnye i gendernye aspekty [Modern labor migration from Kalmykia and Tuva: economic, socio-cultural and gender aspects]. New Research of Tuva, 2021, no. 4, pp. 186-205 (In Russ.). DOI: https://www.doi.org/10.25178/ nit.2021.4.14

BADMAEVA, Nogan Viacheslavovna, Research Fellow, Department of Complex Monitoring and Information Technologies, Kalmyk Scientific Center of the Russian Academy of Sciences. Postal address: 8 Ilishkin St., Elista 358000 Russian Federation. Tel.: +7 (84722) 3-55-06 E-mail: badmaevanv@kigiran.com

ORCID ID: 0000-0002-4799-5506

NATSAK, Organa Dorzhuevna, Candidate of Philosophy, Academic Secretary, Tuvan Institute of Humanities and Applied Social and Economic Research under the Government of the Republic of Tuva. Postal address: 4 Kochetov St., 667000 Kyzyl, Russian Federation. Tel.: + 7 (394-22) 2-39-36. E-mail: nod695596@gmail.com 


\section{Введение}

Исследование масштабов и характера, интенсивности внутренней миграции в России стало актуальным научным направлением в связи с современными изменениями миграционных тенденций, которые затрагивают не только экономические аспекты развития, но и качество человеческого капитала в регионах. Учитывая тот факт, что ряд субъектов РФ, как, например, Тува и Калмыкия, имеют высокий уровень бедности, напряженности на региональных рынках труда, важно не только проводить исследования сравнительного характера между регионами, но и более внимательно изучать влияние доходной дифференциации российских регионов на темпы и направления межрегиональной трудовой миграции.

У упомянутых республик есть общее направление трудовой миграции населения в районы Крайнего Севера и Дальнего Востока, которое практически не изучалось. Актуальность исследования обусловлена необходимостью прогнозирования миграционного потенциала двух регионов, влияния межрегиональной трудовой миграции на социально-демографическую ситуацию и на качество человеческого потенциала в обеих республиках.

Анализом общей миграционной ситуации в Туве занималась М. А. Хольшина (Хольшина, 2010), социологическим изучением въездной миграции в Туву - А. С. Сарыглар (Сарыглар, 2019), этнорегиональными аспектами миграционных процессов 3. В. Анайбан и Г. Ф. Балакина (Анайбан, 2020; Балакина, Анайбан, 2016). В Калмыкии основные тенденции миграционных процессов в постсоветский период анализировали С. С. Белоусов (Белоусов, 2006), М. Б. Убушаев (Убушаев, 2009), различные аспекты трудовой и образовательной миграции - Л. В. Намруева (Намруева, 2011, 2013), Н. А. Эльдяева, Е. С. Кованова (Джамбинова), Д. М. Мучкаев (Эльдяева, Джамбинова, Мучкаев, 2011; Эльдяева, Кованова, 2018).

Целью настоящей статьи является анализ особенностей современной трудовой миграции из республик Калмыкия и Тыва в районы Крайнего Севера и Дальнего Востока, ее экономических, социокультурных и гендерных аспектов.

Для достижения данной цели авторами были поставлены следующие исследовательские задачи: проанализировать российские тренды в области внутренней миграции, изменяющиеся модели миграционного поведения населения двух республик, социально-экономические детерминанты миграции, изучить сам процесс трудовой миграции, включающий принятие решения о миграции, поиск работы, направления миграции и адаптация к климатическим особенностям севера, дальнейшие их жизненные стратегии, связи с малой родиной, сохранение этнической и религиозной идентичностей, финансовую помощь родственникам и др., а также рассмотреть гендерные аспекты трудовой миграции.

Эмпирической основой статьи являются результаты социологических исследований качественного характера. Авторами были проведены глубинные полуформализованные интервью с выходцами из Калмыкии и Тувы, которые живут и работают в регионах Крайнего Севера и Дальнего Востока. Интервью были проведены методом телефонного опроса в период с марта по июнь 2021 г. Всего было проинтервьюировано 43 человека (в Калмыкии 20 чел., все калмыцкой национальности, 10 мужчин и 10 женщин; возрастной состав: 18-29 лет - 3 чел., 30-39 лет -7 чел., 40-49 лет - 6 чел., 50-59- 4 чел.; в Туве опрошено 23 чел., все тувинской национальности, из них 19 женщин и 4 мужчины; возрастной состав: 18-29 лет -2 чел., 30-39 лет -8 чел., $40-49$ лет -8 чел., 50-59 лет -4 чел. и 1 человек старше 60 лет).

Выбор метода исследования связан с необходимостью углубленного изучения происходящих миграционных процессов, не только причин и факторов миграции, но и опыта жизни и работы вдали от малой родины. Среди интервьюируемых из Калмыкии были представители разных профессиональных групп, респонденты из Республики Тыва - представители профессиональной группы медицинских работников, что связано с реализацией в регионах-реципиентах специальных программ привлечения медицинских работников, приведшие к активной миграции этой группы работников.

Также были использованы результаты социологического исследования социально-экономических процессов в Республике Тыва - количественного опроса, предпринятого в 2021 г. Центром изучения социальной структуры и социального расслоения Института социологии ФНИСЦ РАН под руководством д. ф. н., проф. 3. Т. Голенковой в части, касающейся миграционных интенций населения Республики Тыва. Один из соавторов статьи (О. Д. Натсак) являлась участником исследования. 
В социальных сетях присутствуют многочисленные этнические сообщества, состоящих преимущественно из представителей студенческой и трудовой миграции из Республики Тыва в крупных городах, как Москва, Санкт-Петербург. Эти группы в социальной сети Вконтакте, в мессенджере Viber объединяют тысячи людей. Например, сообщество Вконтакте «Санкт-Петербургское тувинское землячество» объединяет 10,2 тыс. участников, «Тыва подслушано в Москве» - 4,7 тыс. чел. Допустим, что данный ресурс также включает участников, которые когда-либо учились и работали в СанктПетербурге, но вернулись в республику. В этой связи состав сетевых групп не может быть источником количества мигрантов, но может давать представление о масштабах общей выездной миграции из республики в те или иные российские города.

\section{Волны миграции в истории тувы и Калмыкии}

Исторически Тува являлась реципиентом миграционных потоков извне. Данные процессы начались еще в Цинское время (вторая половина XVIII - начало XX в.)., а усилились в период протектората царской России над Урянхайским краем.

Первая миграционная волна в Урянхайский край началась с вольным переселением русских крестьян в 80-х гг. ХІХ в., затем происходило проникновение русского капитала и торговцев, интенсивность которого зависело от характера российско-китайских отношений (История Тувы, 2001: 284-286). Официальное разрешение на поселение в Урянхайском крае русские переселенцы получили в 1885 г. (там же: 288). Вторая волна приходится на период Тувинской Народной Республики (1921-1944 гг.). Русская Самоуправляющаяся Трудовая колония (РСТК) формировалась как за счет потоков русских из советской России, так и за счет естественного прироста населения. По данным, который приводит в своем исследовании Н. М. Моллеров, РСТК в 1921 г. насчитывала 9,7 тыс. русского населения, в 1929 г. 12,2 тыс. чел., в 1932 г. - 11,8 тыс. чел. (Моллеров, 1989: 142). После присоединения Тувы к СССР в 1944 г. началась новая - третья миграционная волна, которая носила также социально-экономический характер в рамках общих миграционных процессов большого государства, частью которого стала Тува. Это был приток советских специалистов разных профилей, которые прибывали в Туву по направлению на временную трудовую миграцию для ускоренного выравнивания социально-экономического развития региона в целом, и для реализации конкретных промышленных, инфраструктурных проектов. Эту въездную миграцию, которая носила временный трудовой характер, в научной литературе советского периода называли «механическим приростом» (Николаева, 1967: 211). И она была связана с развертыванием в Туве крупных комбинатов «Туваасбест», «Тувакобальт», автодороги «Ак-Довурак Абаза». В 1959 г. «механический прирост» населения Тувы составил 3208 чел., в 1965 г. - 3478 чел.; это были потоки в основном из регионов Восточной и Западной Сибири (там же: 212-213).

Новая четвертая миграционная волна в Туве началась в постсоветский период. По данным 3. В. Анайбан и Г. Ф. Балакиной, исследовавших этнорегиональную специфику миграционных процессов в Туве, интенсивные миграционные процессы 1990-х гг. отразились в количественном соотношении русского и тувинского населения и моноэтнизации полиэтничных в советкий период районов (Балакина, Анайбан, 2016: 85). Полагаем, отток русскоязычного населения был во многом связан с возвратной трудовой миграцией тех, кто прибыл ранее в Туву. В этой волне миграции коренное население практически не участвовало, при этом очень интенсивно среди коренного населения шли процессы внутрирегиональной миграции по направлению «село - город», приведшие к изменению соотношения городского и сельского населения.

На следующем - пятом этапе волна миграции изменила свою структуру. Исследователи отмечают, что под влиянием внутрирегиональных социально-экономических факторов и общероссийских тенденций, за 2005-2016 гг. изменилась структура внутренней миграции населения России, при которой наблюдается стабильное снижение удельного веса миграции населения внутри субъектов РФ и соответствующее увеличение доли межрегиональных перемещений (Трубин и др., 2018: 11). Этому способствовало облегчение условий для внутренней миграции, дифференциация возможностей удовлетворения жизненных потребностей в субъектах РФ (там же: 13).

Для Тувы изменения миграционной структуры были связаны со все более увеличивающейся невозвратностью студенческой миграции, когда получившая профессиональное образование молодежь начинает или продолжает трудовую деятельность в городах обучения или мигрирует дальше в другие города России. 
Рост трудовой миграции как низкоквалифицированной, так и высококвалифицированной части рабочей силы происходил за счет выезда в крупные города, как Москва, Санкт-Петербург, а также для сезонных работ в таких отраслях, как рыбопереработка, на Камчатке; выезда квалифицированных специалистов, как медицинские работники, в регионы Крайнего Севера и Дальнего Востока, где наблюдается убыль населения или его устойчивое сокращение, активизируется пространственная мобильность коренного населения Тувы. Несмотря на напряженность на региональном рынке труда и иные социальные проблемы, как высокие цены на жилье, низкая доступность социальной инфраструктуры в столице республики, внутренняя миграция по линии «село - город» продолжает сущестовать (см.: Харунова, Харунов, 2021: 145; Тиникова, 2018: 251).

Исторические этапы миграционных процессов на территории современной Калмыкии, как и в Туве, также менялись в связи с особенностями исторического развития регионов. Калмыки вошли в состав России в 1609 г. Территория Калмыкии, как и Республики Тыва, также на протяжении длительного времени являлась реципиентом миграционных потоков извне. Первую волну (дореволюционный период) миграции на территории современной Калмыкии можно охарактеризовать заселением земель крестьянами из различных губерний, где существовала острая нехватка земель (немцы из Бессарабской и Черниговской губерний, эстонцы из Эстляндской и Лифляндской губерний). Вторая волна миграции связана с советским периодом, когда миграция планировалась и организовывалась управленческими органами для достижения, в первую очередь, народнохозяйственных задач. Проблема нехватки квалифицированных кадров привлекла в республику представителей различных национальностей. В Калмыкию, как и в Туву, приезжали специалисты для строительства объектов промышленности, сельского хозяйства, социальной инфраструктуры и т. д.

Третья волна миграции связана с последствиями распада СССР. В Калмыкии, как и в Туве, русское население выезжало из республики, но при этом в Калмыкию в силу ее соседства с такими регионами, как Ставропольский, Краснодарский край, Ростовская, Волгоградская области, которые являлись реципиентами потоков мигрантов из бывших советских республик, также прибывало большое количество переселенцев. В Калмыкию также прибывали потоки беженцев из зон военных действий или этнических конфликтов. В Туву, в силу ее географической отдаленности такие потоки не прибывали.

Таким образом, в общей динамике миграционных процессов в истории Тувы выделяется пять этапов волн, в Калмыкии - три. Межрегиональная трудовая миграция коренного населения Тувы формируется только на пятом этапе, с этой точки зрения Тува становится в незначительной степени, но все же донором трудовых мигрантов в регионы России. Калмыкия также выступает донором межрегиональных трудовых мигрантов. В настоящее время миграционные волны изменились как в Калмыкии, так и в Туве, речь идет, прежде всего, об оттоке населения.

\section{Демографическая ситуация и современные миграционные процессы}

Миграция населения в значительной степени влияет на численность населения республик. Рассмотрим естественный и миграционный прирост населения в Калмыкии и Туве (таб. 1).

Как мы видим, в Калмыкии наблюдаются депопуляционные процессы: естественный прирост населения значительно сокращается, в 2020 г. отмечается отрицательный естественный прирост населения. Эти процессы происходят на фоне миграционной убыли населения региона. Тенденция сокращения численного состава населения в республике сохранится в будущем, поскольку в фертильный возраст вступило малочисленное поколение конца 1990-х - начала 2000-х годов.

В Туве наоборот происходит рост численности населения за счет естественного прироста населения. Общий прирост населения в Туве с 2012 до 2020 г. в среднем составил около трех тысяч человек. Показатель естественного прироста в Туве является одним из самых высоких среди субъектов Российской Федерации. По сравнению с Калмыкией миграционный отток в Туве значительно сокращается.

Рассмотрим процессы трудовой миграции на основе данных о миграции рабочей силы.

На рис. 1 представлена динамика миграции рабочей силы из рассматриваемых республик. По данным диаграммы мы видим, что показатель исходящей трудовой миграции из Тувы значительно ниже данного показателя в Калмыкии. Тенденцию роста миграции рабочей силы мы наблюдаем как в Туве, так и в Калмыкии: в Туве с 0,3 до 1; в Калмыкии с 11,9 до 15,6. Но при этом в Туве кривая показателя более 
поступательна, не наблюдается резких скачков или падений. В Калмыкии самые высокие показатели отмечаются в 2012, 2016 и 2018 годах, при этом наблюдаются резкие спады в 2015 и в 2017 гг.

Таблица 1. Изменение численности постоянного населения Республики Калмыкия и Республики Тыва по компонентам (2012-2020 г2.) $)^{1}$

Table 1. Changes in permanent population of the republics of Kalmykia and Tuva by component, 2002-2020.

\begin{tabular}{|c|c|c|c|c|c|c|}
\hline & \multicolumn{2}{|c|}{ Общий прирост } & \multicolumn{2}{c|}{ Естественный прирост } & \multicolumn{2}{c|}{ Миграционный прирост } \\
\cline { 2 - 7 } & Калмыкия & Тува & Калмыкия & Тува & Калмыкия & Тува \\
\hline 2020 & -1151 & 2985 & -255 & 3570 & -896 & -585 \\
\hline 2019 & -1512 & 2960 & 253 & 3342 & -1765 & -382 \\
\hline 2018 & -2766 & 2701 & 398 & 3681 & -3164 & -980 \\
\hline 2017 & -2390 & 3172 & 290 & 4227 & -2680 & -1055 \\
\hline 2016 & -930 & 2913 & 747 & 4256 & -1677 & -1343 \\
\hline 2015 & -1831 & 1860 & 1048 & 4240 & -2879 & -2380 \\
\hline 2014 & -1457 & 2016 & 1182 & 4502 & -2639 & -2486 \\
\hline 2013 & -2119 & 1301 & 1321 & 4712 & -3440 & -3411 \\
\hline 2012 & -2549 & 1113 & 1398 & 4795 & -3947 & -3682 \\
\hline
\end{tabular}

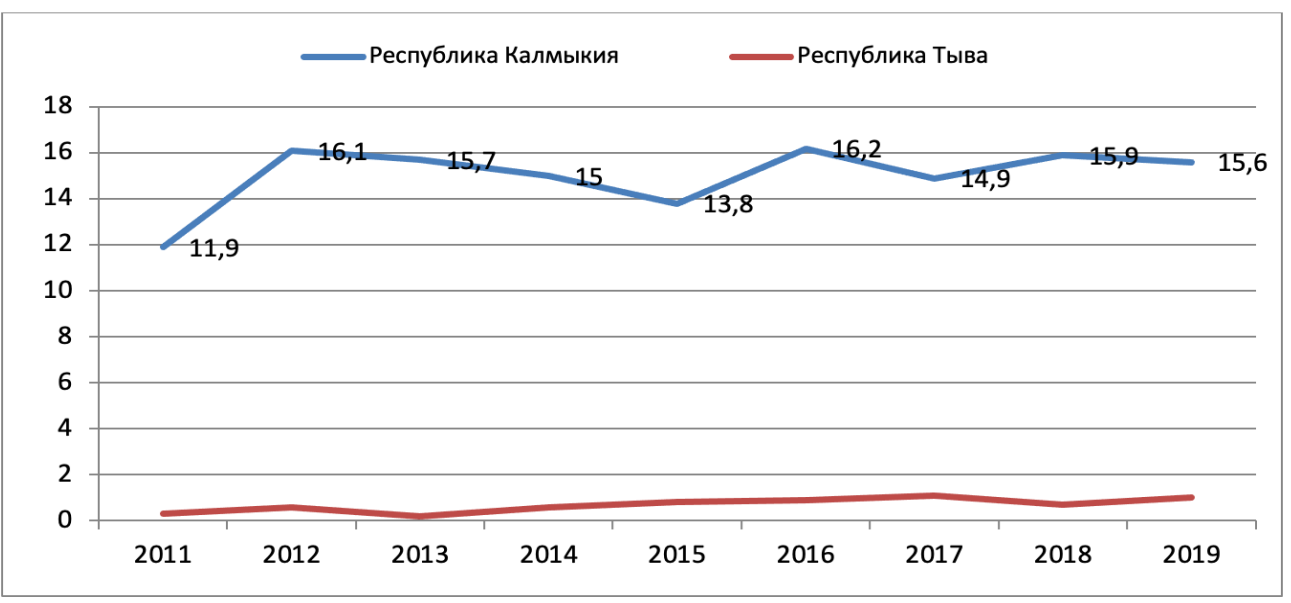

Рис. 1. Динамика внутрироссийской трудовой миграции из Республики Калмыкия и Республики Тыва по данным выборочного обследования рабочей силы, 2011-2019 г2., тыс. чел. ${ }^{2}$

Fig. 1. Changes in internal labor migration from the republics of Kalmykia and Tuva, 2011-2019 (thousands), based on a selective survey of labor force.

Если сравнивать с данными по другим субъектам РФ в 2019 г. ${ }^{3}$, Республика Тыва имеет один из самых низких показателей миграционной подвижности населения трудоспособного населения. Наибольшие значения данного показателя наблюдались в Московской области (20,2\%), Ленинградской области (18,35\%), из национальных республик - в Республике Адыгея (16,4\%), Чувашской Республике (13,85\%), Республике Калмыкия (12,7\%).

\footnotetext{
${ }^{1}$ Изменение численности постоянного населения по субъектам Российской Федерации по компонентам. Численность и миграция населения Российской Федерации (2012-2020 гг.) [Электронный ресурс] // Федеральная служба государственной статистики. URL: https://rosstat.gov.ru/compendium/document/13283 (дата обращения: 18.08.2021); Численность населения Тувы по компонентам [Электронный ресурс] // Управление Федеральной службы государственной статистики по Красноярскому краю, Республике Хакасия и Республике Тыва. URL: https://krasstat.gks.ru/folder/32956 (дата обращения 18.08.2021).

${ }^{2}$ О межрегиональной трудовой миграции в 2019 году [Электронный ресурс] // Федеральная служба государственной статистики. URL: https://rosstat.gov.ru/storage/mediabank/GhpJyhEX/mtm_2019.pdf (дата обращения 15.08.2021).

${ }^{3}$ О межрегиональной трудовой миграции в 2019 году [Электронный ресурс] // Федеральная служба государственной статистики. URL: https://rosstat.gov.ru/storage/mediabank/GhpJyhEX/mtm_2019.pdf (дата обращения 15.08.2021).
} 
В процентах к численности занятого населения Республики Тыва выезжающие на работу в другие субъекты в 2019 г. составили $1 \%{ }^{1}$.

Однако можно предположить, что статистические данные по результатам выборочных обследований рабочей силы не в полной мере могут учитывать фактическую миграционную активность. Территориальная мобильность трудоспособного населения Тувы может быть выше. Основанием для этой гипотезы служат результаты социологического исследования социально-экономических процессов в Республике Тыва, проведенного в мае 2021 г. сотрудниками Центра изучения социальной структуры и социального расслоения Института социологии ФНИСЦ РАН. В исследовании наряду с другими вопросами социально-экономического характера анализировались миграционные интенции населения в целях временной и постоянной работы на внутрирегиональном и межрегиональном уровне. Опрос жителей республики ${ }^{2}$ показал, что потенциал межрегиональной трудовой миграции в Туве высок - около 28\% опрошенных желают выехать для сезонных работ в другой регион, $29 \%$ рассматривают возможность переезда в другой город/село республики или другой регион для поиска более подходящей работы. Как известно, намерение выехать в целях поиска работы или трудоустройства за пределы административных границ соответствующего субъекта - это уже первая стадия миграционного движения (Рыбаковский, 2020: 342-356).

По валовым показателям внутренних миграционных процессов 2020 г. (по числу прибывших из других регионов и числу выбывших в другие регионы) наблюдается отрицательное миграционное сальдо: из Республики Тыва выбыло больше, чем прибыло, миграционная убыль составила 579 чел. ${ }^{3}$ С учетом вышесказанного, а также на основе изучения демографического прогноза Росстата до 2035 г. по естественному приросту населения, динамики численности населения в трудоспособном возрасте по среднему и высокому вариантам (без учета низкого варианта) (таб. 2) можно предположить, что межрегиональная трудовая миграция из Республики Тыва будет только расти. Республика Тыва отличается от других субъектов РФ положительным естественным приростом, что означает, что демографическое давление на региональный рынок труда будет усиливаться за счет роста населения в целом и роста числа населения трудоспособного возраста (по среднему варианту в 2021 г. - 180,1 тыс. чел., в 2035 г. - 227 тыс. чел.) $)^{4}$. Это предположение подкрепляется также прогнозом Росстата относительно показателя миграционного прироста - по этому прогнозу с 2021 г. до 2035 г. миграционное сальдо в Республике Тыва по всем трем вариантам будет сплошь отрицательным, то есть выбывать будут больше, чем прибывать. И именно за счет темпов естественного прироста отрицательное миграционное сальдо не будет критичным для региональной экономики.

В Калмыкии по демографическому прогнозу Росстата миграционный прирост населения сохранит негативную динамику, однако будет иметь тенденцию к уменьшению. Это, на наш взгляд, будет связано с общим сокращением численности населения, а также сокращением численности населения трудоспособного возраста.

Таким образом, анализ современных миграционных процессов в Туве и Калмыкии показал, что в Калмыкии эти процессы наиболее интенсивны, что влияет на сокращение численности населения региона в целом. В Туве в последние годы интенсивность миграционных процессов падает, хотя в 2012 г. показатели миграционного оттока в Калмыкии и Туве составляли соответственно 3947 и 3682 человек. Демографическая ситуация в республиках также отличается. В Туве наблюдаются одни из самых высоких в стране коэффициенты рождаемости, рост числа населения моложе трудоспособ-

\footnotetext{
${ }^{1}$ O межрегиональной трудовой миграции в 2019 году [Электронный ресурс] // Федеральная служба государственной статистики. URL: https://rosstat.gov.ru/storage/mediabank/GhpJyhEX/mtm_2019.pdf (дата обращения 15.08.2021).

${ }^{2}$ Генеральную совокупность, служащую основой для построения выборочной совокупности при проведении исследования, составило все население Республики Тыва старше 18 лет. Выборочная совокупность составила 1539 ед. Исследование проходило в 88 населенных пунктах Республики Тыва. Методом сбора информации являлось 20-минутное личное интервью, которое поводилось по формализованному опроснику.

${ }^{3}$ Миграция населения в 2020 году [Электронный ресурс] // Управление Федеральной службы государственной статистики по Красноярскому краю, Республике Хакасия и Республике Тыва. URL: https://krasstat.gks.ru/news/ document/115299? print=1 (дата обращения 03.08.2021).

${ }^{4}$ Предположительная численность населения Российской Федерации до 2035 года. Статистический бюллетень. M., 2020 [Электронный ресурс] // Федеральная служба государственной статистики. URL: https://rosstat.gov.ru/ compendium/document/13285?print=1 (дата обращения 08.08.2021).
} 
ного возраста и общей численности населения в целом, в Калмыкии же происходят депопуляционные процессы, когда стремительно сокращается рождаемость и растет смертность населения, особенно трудоспособного возраста.

Таблица 2. Миграционный прирост населения Республики Тыва и Республики Калмыкия по демографическому прогнозу Росстата до 2036 г. (средний вариант) ${ }^{1}$

Table 2. Migration balance in the republics of Tuva and Kalmykia, from Rosstat's demographic forecast up to the year 2036 (the middle-way scenario).

\begin{tabular}{|c|c|c|}
\hline Годы & Республика Тыва & Республика Калмыкия \\
\hline 2021 & -949 & -1700 \\
\hline 2022 & -997 & -1687 \\
\hline 2023 & -1051 & -1626 \\
\hline 2024 & -1051 & -1591 \\
\hline 2025 & -1087 & -1573 \\
\hline 2026 & -1146 & -1513 \\
\hline 2027 & -1182 & -1468 \\
\hline 2028 & -1241 & -1428 \\
\hline 2029 & -1268 & -1399 \\
\hline 2030 & -1299 & -1363 \\
\hline 2031 & -1367 & -1330 \\
\hline 2032 & -1391 & -1263 \\
\hline 2033 & -1425 & -1262 \\
\hline 2034 & -1478 & -1202 \\
\hline 2035 & -1521 & -1203 \\
\hline
\end{tabular}

\section{Основные детерминанты межрегиональной трудовой миграции}

Считается, что основным детерминантом межрегиональной трудовой миграции является уровень социально-экономического развития регионов. Исследователи отмечают, что из всей совокупности факторов миграции в современной России на внутренние миграционные потоки оказывают влияние экономические показатели, прежде всего, уровень благосостояния населения и ситуация на региональном рынке труда (Алешковский, 2007: 19). Кроме экономических параметров развития региона и уровня жизни населения при изучении интенсивности внутренней миграции авторы рассматривают уровень доступности социальной инфраструктуры, а также уровень преступности (Трубин и др., 2018: 4).

Для нашего исследования рассмотрим доходы населения и ситуацию на рынке труда двух регионов, а также уровень экономического развития в сравнительном контексте с другими российскими регионами.

Калмыкию и Туву объединяют высокие показатели монетарной бедности населения. В период с 2013 по 2020 г. уровня 30\% бедного населения, помимо Тувы, достигали только два российских региона: Республика Калмыкия (2013-2014 гг.) и Республика Ингушетия (2018-2020 гг.)². В 2013 году самым бедным регионом была Республика Калмыкия, с 2014 г. у данной республики наблюдается снижение бедности, однако показатели Калмыкии $(22,7 \%)$ и Тувы $(34,1 \%)$ в 2020 г. существенно превышают среднероссийское значение доли населения с денежными доходами ниже прожиточного минимума $-12,1 \%^{3}$.

\footnotetext{
${ }^{1}$ Предположительная численность населения Российской Федерации до 2035 года. Статистический бюллетень. M., 2020 [Электронный ресурс] // Федеральная служба государственной статистики. URL: https://rosstat.gov.ru/ compendium/document/13285?print=1 (дата обращения 08.08.2021).

${ }^{2}$ Социально-экономические индикаторы бедности в 2013-2020 гг. М., 2021. С. 22. [Электронный ресурс] // Федеральная служба государственной статистики. URL: https://rosstat.gov.ru/folder/11110/document/13293?print=1 (дата обращения: 15.08.2021).

${ }^{3}$ Там же.
} 
Предпринимая попытку проследить корреляцию между уровнем доходов населения и интенсивностью выездной межрегиональной миграции населения, приходим к выводу о том, что применительно к отдельным субъектам эта связь не всегда очевидна. Республика Тыва имеет один из самых низких показателей среднедушевых денежных доходов населения среди субъектов РФ, в IV кв. 2020 г. он составил 22825 руб., в Ингушетии, к примеру, этот показатель составил 20978 руб. ${ }^{1}$ При этом в данных регионах наблюдаются одни из низких показателей по доле населения, работающего за пределами своего субъекта. Республика Калмыкия, имея среднедушевой доход 25464 руб., т. е. чуть выше, чем в указанных регионах, имеет в разы больше показатель по доле населения, выезжающего за пределы своего субъекта - 12,9\%². Как мы полагаем, в данном случае важен фактор географического положения Калмыкии, близость к центру, а также история миграции коренного населения, длительность и интенсивность которой отличается от Тувы.

Корреляция между высоким уровнем среднедушевых доходов в регионах-реципиентах и выездом внутренних трудовых мигрантов именно в эти регионы более очевидна. Регионы направлений межрегиональной трудовой миграции имеют наиболее высокие среднедушевые доходы: Ямало-Ненецкий автономный округ - 90633 руб., Чукотский АО - 99640 руб., Сахалинская область - 71935 руб., Камчатский край -65813 руб. ${ }^{3}$ и т. д.

По показателям безработицы в 2019 г. Республика Тыва (12,3\%) входила в число регионов с худшими показателями после Республики Ингушетия, Чеченской Республики, Республики Дагестана ${ }^{4}$ При этом динамика снижения уровня безработицы в Республике Тыва, начиная с 2006 г., является существенной - с 20,3\% в 2006 г. до 12,3\% - в 2019 г.

Рассмотренная нами корреляция между интенсивностью межрегиональной миграции и показателями безработицы населения в указанных субъектах РФ неочевидна, так как ни один из этих четырех регионов с самыми высокими показателями безработицы не входят в двадцатку регионов-лидеров по доле населения, работающего за пределами своего субъекта в среднем за 2019 г. По Республике Тыва эти показатели в динамике с 2006 по 2019 гг. можно увидеть на рис. 2. Примечательно то, что Республика Ингушетия с худшим показателем по безработице в 2019 г. имела один из самых минимальных показателей выездной межрегиональной миграции (0,3 тыс. чел.), также Республика Тыва (1,0 тыс. чел.), Чеченская Республика (2,3 тыс. чел.), в Калмыкии этот показатель составил 15,6 тыс. чел. ${ }^{5}$ Это говорит о том, что напряженность на рынке труда не всегда является решающим фактором, способствующим межрегиональной миграционной активности, но может в совокупности с другими факторами влиять на миграционную мобильность.

Значит, есть другие важные факторы. Какие именно? Может ли это быть фактор языка?

Рассмотрим корреляцию между интенсивностью межрегиональных миграционных перемещений и владением русским языком в Калмыкии и Туве. По результатам Всероссийской переписи населения 2010 г. в Республике Калмыкия 97,61\% населения владеют русским языком, в Республике Тыва -

\footnotetext{
${ }^{1}$ Среднедушевые денежные доходы населения по субъектам Российской Федерации 2020 г. [Электронный ресурс] // Федеральная служба государственной статистики. URL: https://rosstat.gov.ru/folder/13397?print=1. (дата обращения 10.08.2021).

${ }^{2}$ О межрегиональной трудовой миграции в 2019 г. [Электронный ресурс]// Федеральная служба государственной статистики. URL: https://rosstat.gov.ru/storage/mediabank/GhpJyhEX/mtm_2019.pdf (дата обращения 10.08.2021). ${ }^{3}$ Среднедушевые денежные доходы населения по субъектам Российской Федерации 2020 г. [Электронный ресурс] // Федеральная служба государственной статистики. URL: https://rosstat.gov.ru/folder/13397?print=1 (дата обращения 10.08.2021).

${ }^{4}$ Там же.

${ }^{5}$ О межрегиональной трудовой миграции в 2019 г. [Электронный ресурс]// Федеральная служба государственной статистики. URL: https://rosstat.gov.ru/storage/mediabank/GhpJyhEX/mtm_2019.pdf (дата обращения 10.08.2021). ${ }^{6}$ Национальный состав и владение языками, гражданство: итоги Всероссийской переписи населения 2010 года. Элиста: Территориальный орган федеральной службы государственной статистики по Республике Калмыкия, 2013. С. 12, 137; Республика Тыва. Национальный состав и владение языками, гражданство // Всероссийская перепись населения 2010 г. [Электронный ресурс] // Управление Федеральной службы государственной статистики по Красноярскому краю, Республике Хакасия и Республике Тыва. URL: https://krasstat.gks.ru/ folder/39102 (дата обращения: 23.08.2021); Республика Ингушетия. Национальный состав и владение языками, гражданство / Всероссийская перепись населения 2010 г. Электронный ресурс] // Управление Федеральной службы государственной статистики по Северо-Кавказскому федеральному округу. URL: https://stavstat.gks.ru/ folder/39776 (дата обращения 23.08.2021).
} 


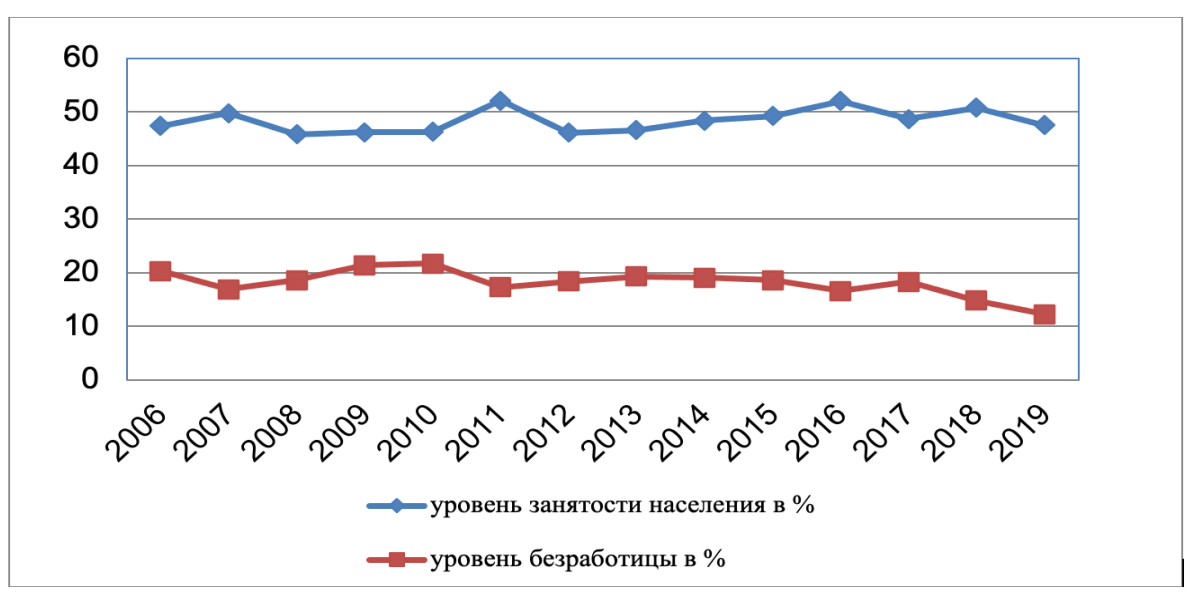

Рис 2. Динамика показателей уровня занятости и уровня безработицы в Республике Тыва в 2006-2019 22., в \% ${ }^{1}$

Fig. 2. Changes in the levels of employment and unemployment in the Republic of Tuva, 2006-2019,\%.

$84,7 \%^{6}$. При этом в Калмыкии только 24,73\% жителей региона владеют калмыцким языком, число представителей титульной национальности, владеющих калмыцким языком, за межпереписной период (с 2002 по 2010 гг.) сократилось почти в два раза (1,97) (Кованова, Бадмаева, Удаев 2019: 1100). В Туве число владеющих тувинским языком лиц, указавших принадлежность к тувинской национальности, составило по переписи населения 2010 г. 97\% (241092 чел. из 249299 чел.) ${ }^{2}$. На владение русским языком указало 82\% тувинцев (204 213 из 249299 чел.) $)^{3}$, что является высоким показателем.

Л. Б. Четырова отмечает, что калмыки в большинстве своем являются русскоязычным народом, который при этом сохраняют высокую языковую лояльность к своему языку (Четырова, 2012: 16). Однако у калмыков билингвизм: русско-калмыцкий, а у тувинцев - тувинско-русский. В данном случае более важным является временная разница «подключения» калмыков и тувинцев к общероссийскому социокультурному пространству и к межрегиональной миграции.

Таким образом, гипотеза о том, что языковой фактор влияет на темпы межрегиональной миграции - не подтвердилась.

Более убедительным является тезис о том, что невозможность для Калмыкии и Тувы конкурировать по уровню жизни, оплаты труда с регионами, куда выезжают трудовые мигранты, главным образом влияет на интенсивность миграционного движения.

Ранжирование мест, занимаемых субъектами РФ по основным социально-экономическим показателям за 2019 г., показывает, что по поступлениям налогов, сборов и иных обязательных платежей в бюджетную систему РФ на душу населения ЯНАО занимает 1 место, Сахалинская область - 4-е, Камчатский край - 26-е, Республика Калмыкия - 76-е, Республика Тыва - 79-е. По валовому региональному продукту (ВРП) в 2018 г. и инвестициям в основной капитал на душу населения ЯНАО (2 место), Сахалинская область (4-е и 5-е места соответственно) также находятся в лидерах, а Камчатский край - в первой двадцатке (13-е и 15-е места соответственно), Республика Калмыкия - 65 и 69 места соответственно, Республика Тыва занимает 76-е и 73-е места соответственно ${ }^{4}$. В силу такой неравномерности социально-экономического развития и бюджетных возможностей экономически

\footnotetext{
${ }^{1}$ Рабочая сила, занятость и безработица в России 2020 [Электронный ресурс] // Федеральная служба государственной статистики. URL: https://rosstat.gov.ru/folder/210/document/13211?print=1 (дата обращения: 07.08.2021).

${ }^{2}$ Всероссийская перепись населения 2010. Республика Тыва [Электронный ресурс] // Управление Федеральной службы государственной статистики по Красноярскому краю, Республике Хакасия и Республике Tыва. URL: https://krasstat.gks.ru/folder/39102?print=1 (дата обращения: 28.09.2021).

${ }^{3}$ Там же.

${ }^{4}$ Регионы России. Социально-экономические показатели. Официальное издание. М.: Федеральная служба государственной статистики, 2020. С. 34.
} 
слабым регионам практически невозможно конкурировать с высокодоходными субъектами РФ в удержании квалифицированных специалистов, особенно, если в регионах-реципиентах приняты специальные программы привлечения и финансового стимулирования притока специалистов, например врачей.

Миграционные возможности населения разной доходной стратификации неравны даже при высоком миграционном потенциале. Полагаем, что одним из факторов реализации миграционных намерений населения является наличие финансовых средств для переезда и первичного обустройства в новом регионе. В отличие от профессионализированных миграционных потоков, как у медицинских работников или учителей, которые условно назовем «программной трудовой миграцией», когда выехавшие в новый регион специалисты получают социальный пакет из единоразовых выплат, предоставления жилья, «непрограммные» трудовые мигранты самостоятельно несут все издержки, связанные с переездом, поиском работы, жилья. С этой точки зрения для многих лиц, имеющих миграционные намерения, сам процесс переезда может быть недоступным.

Социологическое исследование, проведенное в Республике Тыва в 2021 г., показало, что переезд в другие регионы страны на сезонные работы рассматривают, но не имеют возможности в большей степени именно представители самой малообеспеченной группы по материальной самооценке (34,3\%).

Таблица 3. Миграционные интенции населения (межрегиональная миграция) Республики Тыва, в \%

Table 3. Migration capability of the population of the Republic of Tuva (interregional migration), \%.

\begin{tabular}{|c|c|c|c|c|}
\hline & \multicolumn{4}{|c|}{$\begin{array}{c}\text { Рассматриваете ли вы для себя возможность поехать } \\
\text { на сезонные работы в другой регион или вы такой вариант } \\
\text { не рассматриваете? }\end{array}$} \\
\hline & Да & $\begin{array}{c}\text { Скорее да, чем } \\
\text { нет }\end{array}$ & $\begin{array}{l}\text { Скорее нет, } \\
\text { чем да }\end{array}$ & Hem \\
\hline Денег не хватает даже на питание & 34,3 & 11,6 & 9,7 & 41,7 \\
\hline Денег хватает только на питание & 14,8 & 12,2 & 9,5 & 58,9 \\
\hline $\begin{array}{c}\text { На питание и одежду денег хватает, но } \\
\text { более крупные покупки приходится } \\
\text { откладывать, брать кредит }\end{array}$ & 14,4 & 14,9 & 12,7 & 55,9 \\
\hline $\begin{array}{c}\text { Денег вполне хватает на покупку крупной } \\
\text { бытовой техники, но мы не можем купить } \\
\text { автомашину }\end{array}$ & 10,8 & 7,8 & 18,1 & 61,2 \\
\hline $\begin{array}{c}\text { Денег хватает на все, кроме таких дорогих } \\
\text { приобретений, как квартира, дом }\end{array}$ & 10,6 & 8,3 & 7,5 & 68,7 \\
\hline $\begin{array}{l}\text { Мы можем позволить себе купить машину, } \\
\text { дачу, словом, ни в чем себе не отказываем }\end{array}$ & 7,3 & 6,1 & 21,8 & 64,8 \\
\hline
\end{tabular}

Как мы видим из данных таблицы 3, эта группа населения испытывает существенные материальные затруднения, начиная со статьи расходов - средств на питание, и в этой связи для данной группы затруднителен переезд в другой регион в поисках работы.

Таким образом, можно сделать вывод о том, что возможность выезда на межрегиональную трудовую миграцию детерминируется также материальными условиями.

\section{Принятие решения о трудовой миграции и причины}

Решение о трудовой миграции в регионы Крайнего Севера и Дальнего Востока респонденты как из Калмыкии, так и из Тувы преимущественно принимали самостоятельно, но обсуждали на семейных советах. Для респондентов из Тувы важным фактором, повлиявшим на их решение о миграции, была необходимость содержания, воспитания и обучения детей. Респонденты из Калмыкии также отмети- 
ли, что решение о миграции не принималось одномоментно, оно обдумывалось в течение нескольких лет: «вынашивала эту идею два года», «думал о миграции на Север в течение трех лет...» и т. д.

Основными причинами выезда в другой регион участники интервью из Республики Тыва указали финансовые трудности, высокую кредитную нагрузку в связи с ранее взятыми потребительскими и ипотечными кредитами. По информации Центробанка о динамике долговой нагрузки населения России, во втором и третьем кварталах 2020 г. на основе данных Бюро кредитных историй, по уровню проникновения кредитования Республика Тыва имеет самый высокий суммарный показатель - 38,4 (доля проникновения - отношение числа заемщиков на отчетную дату в регионе к числу постоянно проживающего населения на начало календарного года) ${ }^{1}$.

Большая часть опрошенных не имела ранее опыта трудовой миграции, однако знали и ориентировались на примеры миграции из круга знакомых лиц.

Респонденты из Калмыкии среди причин миграции указывали неудовлетворенность заработной платой, отсутствие работы. У части респондентов на момент принятия решения о миграции была работа, однако размер заработной платы не позволял совершать крупные покупки, решить квартирный вопрос. Другая часть респондентов имела временные или непостоянные заработки, например, - в такси или в выполнении подсобных работ.

Следует отметить тот факт, что решение о выезде в другие регионы России в поисках работы как среди тувинцев, так и калмыков, принимается на разных жизненных и возрастных этапах: сразу после окончания вуза, в 30 лет, в 40 лет, а также после 50 лет в предпенсионном возрасте. Таким образом, миграционная мобильность характерна для разных возрастных групп, но в рамках трудоспособного возраста.

Так, мы выяснили, что для респондентов из Тувы основной причиной миграции является стратегия оплаты кредитных задолженностей, необходимость обеспечения детей. Для респондентов из Калмыкии миграция в районы Крайнего Севера является возможностью реализации своего профессионального потенциала, развития карьеры, поскольку это невозможно осуществить на своей малой родине.

\section{Поиск работы, удовлетворенность уровнем оплаты труда}

Основным каналом поиска работы и участия в соответствующих кадровых программах для респондентов-тувинцев в другом регионе, по словам участников интервью, явился Интернет: онлайнплатформы вакансий, сайты медицинских организаций. Опрошенные не только искали вакансии, но и размещали резюме на онлайн-платформах, направляли резюме напрямую потенциальным работодателям. Также они получали необходимую информацию по телефону. Другим каналом получения информации об искомой вакансии выступили знакомые и коллеги опрошенных.

Никто из участников интервью не испытывал трудностей с поиском работы, за исключением одного случая, когда достаточно длительное время пришлось ждать решения принимающей стороны. «Трудностей не было. Врачи везде нужны», - сказала женщина, тувинка, 52 г., г. Салехард. «Никаких трудностей. С хорошими знаниями и опытом всегда будет работа», - это слова женщины, тувинки, 39 лет, г. Южно-Сахалинск. Дефицит врачей в регионах миграции, наличие высшего медицинского образования и опыт работы позволяют участникам интервью уверенно себя чувствовать на рынке труда и находить более оплачиваемую работу по своей специальности за пределами Республики Тыва.

На вопрос о том, удовлетворены ли уровнем оплаты труда, участники интервью практически все отвечают положительно. «Удовлетворена, знала, что зарплата будет больше, чем в нашей республике». Есть и те, у которых зарплатные амбиции выше, чем имеющийся на момент интервью уровень, удовлетворенность есть, но есть и стремление к более высокому уровню.

Одним из ключевых факторов трудовой миграции врачей является решение жилищного вопроса со стороны работодателя и администрации района. В ходе интервью было выявлено несколько прак-

\footnotetext{
${ }^{1}$ Анализ динамики долговой нагрузки населения России в II-III кварталах 2020 года на основе данных Бюро кредитных историй. Информационно-аналитический материал. Банк России. 2021. С. 19-20 [Электронный ресурс] // Центральный банк Российской Федерации. URL: https://cbr.ru/Collection/Collection/File/31945/ review_03022021.pdf (дата обращения: 08.04.2021).
} 
тических вариантов предоставления жилья прибывшим врачам: через социальный найм с возможностью последующей приватизации; предоставление служебного жилья работодателем или администрацией муниципального района; компенсация работодателем стоимости аренды жилья, а также самостоятельная аренда жилья с оплатой из собственных доходов врача.

Для респондентов из Калмыкии основными каналами поиска работы выступают земляческие сети. У многих респондентов на Севере работают родственники, друзья, знакомые. Они не только информировали о существующих вакансиях, но и помогали респондентам обустроиться в первое время, предоставляли жилье или помогали с поиском жилья. Наиболее многочисленные калмыцкие мигрантские общины представлены в Ханты-Мансийском, Ямало-Ненецком, Чукотском автономных округах.

Практически все респонденты-калмыки удовлетворены заработной платой. Оценивая материальные результаты своей работы в районах Крайнего Севера, большая часть респондентов отметила, что были решены вопросы с покупкой собственного жилья. Квартиры были приобретены в ипотеку, но часть респондентов ее уже выплатили. Причем приобретены квартиры или частные дома как в Калмыкии, для своего будущего проживания, так и в регионе, где они работают. Также респонденты отметили, что они воспользовались региональной поддержкой: определенный процент ипотечной ставки оплатил регион, в котором они проживают. Покупка недвижимости, на наш взгляд, является для респондентов очевидным, возможно наиболее привычным в целом для России, средством долгосрочного вложения заработанных на Крайнем Севере средств. При этом приобретение недвижимости не является для респондентов конечным результатом миграции, респонденты в своем большинстве продолжают свою профессиональную деятельность.

Полученные результаты позволяют говорить о том, что респонденты из Тувы и Калмыкии выбирают разные каналы поиска работы, если представители Тувы обращаются к интернет-каналам (сайты поиска вакансий, сайты медицинских сообществ и др.), то респонденты из Калмыкии в большинстве своем используют земляческие сети, обращаются к родственникам и друзьям, уже проживающим в районах Крайнего Севера. Такое различие связано с особенностями выборки из Тувы - преобладанием медицинских работников, которые, соответственно, при поиске работы обращаются к своим профессиональным сообществам через Интернет.

\section{Направления трудовой миграции, климатические особенности}

Основным направлением трудовой миграции респондентов из Республики Тыва (врачей) стали Сахалинская область, Ямало-Ненецкий автономный округ, Камчатский край. Участники интервью из Калмыкии живут и работают в следующих регионах: Ямало-Ненецкий автономный округ (гг. Надым, Салехард, Новый-Уренгой, Ноябрьск), Ханты-Мансииийский автономный округ (пгс. Березово, с. Теги), Чукотский автономный округ (гг. Анадырь, Певек), Красноярский край (р-н Талнах г. Норильска). Данные субъекты РФ, расположенные на российском Дальнем Востоке и на Крайнем Севере, испытывают дефицит не только в медицинских работниках, но и в человеческих ресурсах в целом в силу особых климатических условий (ЯНАО), географической удаленности от центральных районов России (Камчатка, Сахалин), островного характера (Сахалин).

В Камчатской области на 1 июня 2021 г. в лечебно-профилактических учреждениях системы здравоохранения имелось 433,25 вакансий ${ }^{1}$. По данным министерства здравоохранения Сахалинской области организациям здравоохранения требовалось 434 медицинских работников на 1 июля 2021 г. По нашему мнению, проблема нехватки медицинского персонала в районах Крайнего Севера и Дальнего Востока является результатом общероссийской проблемы кадров для системы здравоохранения, а именно нежеланием молодых специалистов работать в государственных медицинских учреждениях, где уровень заработной платы ниже, чем в частных клиниках, также нежеланием молодых специалистов работать в отдаленных населенных пунктах в сельской местности и т. д. Все это привело к старению

\footnotetext{
${ }^{1}$ Информация о вакансиях в лечебных учреждениях Камчатского края [Электронный ресурс] // Официальный сайт Правительства Камчатского края. Министерство здравоохранения Камчатского края. URL: https://kamgov. ru/minzdrav/informacia-o-potrebnosti-v-medicinskih-rabotnikah (дата обращения: 01.08.2021).

${ }^{2}$ Потребность по медицинским учреждениям [Электронный ресурс] // Министерство здравоохранения Сахалинской области. URL: https://minzdrav.sakhalin.gov.ru/personnel/need. (дата обращения: 02.08.2021).
} 
кадров в системе здравоохранения, при этом в рассматриваемых нами регионах проблема усугубляется сложными климатическими условиями, которые не способствуют задержке кадров.

Коэффициенты миграционного прироста в принимающих регионах ${ }^{1}$ на 1000 чел. населения за 2019 г. в трех этих регионах имеют отрицательные значения (ЯНАО --24 ; Сахалин --22 ; Камчатка -50)2. Распределение числа прибывших в процентах от общего числа прибывших показывает, что из других регионов России прибыло в ЯНАО 61,3\%, на Сахалин - 35,6\%, Камчатку - 51,8\%3.

Такие регионы имеют специальные меры стимулирования притока специалистов из других регионов России. Так, например, в Сахалинской области врачам-специалистам, прибывшим для трудоустройства после 01.01.2019 г. и заключившим договор о кадровом обеспечении (срок отработки не менее 10 лет), предоставляются дополнительные социальные гарантии в виде единовременной денежной выплаты врачам, оказывающим первичную медико-санитарную помощь в размере от 1560,0 тыс. руб. до 2600,0 тыс. руб., остальным врачам - от 1450,0 тыс. руб. до 2200,0 тыс. руб.; единовременную денежную выплату на покупку жилья в размере до 60\% от стоимости (не более 3000,0 тыс. руб.); компенсации за аренду жилья до 25 тыс. руб. в месяц. Финансовая поддержка предусмотрена также прибывающим в Сахалинскую область фельдшерам, заключившим договор о кадровом обеспечении, в размере от 400,0 до 600,0 тыс. руб., остальному среднему медицинскому персоналу от 270,0 тыс. руб. до 405,0 тыс. руб. (срок отработки не менее 5 лет) 4

Данные регионы выделяются среди других субъектов РФ высоким уровнем зарплаты, например врачей и медицинских работников. Если посмотрим данные Росстата за январь - март 2021 г., то на первом месте по России находится Ямало-Ненецкий автономный округ, где среднемесячная начисленная зарплата врача составляет 236788 руб. Сахалинская область (166802 руб.) и Камчатский край (158095 руб.) занимают пятое и шестое места соответственно после Чукотки (211066 руб.), Магаданской области (176552 руб.) и Ненецкого автономного округа (167614 руб.) $)^{5}$. В этой связи уровень зарплаты врачей в Республике Тыва (64458) ${ }^{6}$ не может конкурировать с уровнем оплаты труда в данных субъектах Российской Федерации.

Указанные регионы отличаются климатическими особенностями, обусловленными близостью к Охотскому, Японскому и Берингово морям, Тихому океану (Сахалинская область, Камчатский край), к многолетней мерзлоте - арктический и субарктический климат в Ямало-Ненецком автономном округе. Эти климатические зоны являются достаточно непривычными для выходцев из Республики Тыва и Республики Калмыкия. Наши респонденты отмечали повышенную влажность дальневосточных регионов, продолжительный холодный период, и суровый климат Ямало-Ненецкого автономного округа. Вместе с тем адаптация к новым климатическим условиям сугубо индивидуальна. Некоторые респонденты не испытывали сложностей, другие не перестают ощущать дискомфорт - такой расклад характерен и для калмыков, и для тувинцев.

При этом большая часть респондентов из Калмыкии отметила, что адаптировалась к климатическим условиям достаточно быстро. Однако они отмечают, что сложно было привыкнуть к полярной ночи или полярному дню, к отсутствию солнца по несколько месяцев, или наоборот к дневному свету в ночное время. Если температуру -30 градусов они переносили достаточно хорошо, то морозы

\footnotetext{
${ }^{1}$ Коэффициент миграционного прироста рассчитывается, исходя из разницы между числом прибывших и числом выбывших за отчетный год, поделенную на среднегодовую численность населения и умноженную на 10000.

${ }^{2}$ Регионы России. Социально-экономические показатели. Официальное издание. М.: Федеральная служба государственной статистики. 2020. С. 91.

${ }^{3}$ Там же. С. 94.

${ }^{4}$ Потребность по медицинским учреждениям [Электронный ресурс] // Министерство здравоохранения Сахалинской области. URL: https://minzdrav.sakhalin.gov.ru/personnel/need. (дата обращения: 02.08.2021).

${ }^{5}$ Средняя заработная плата врачей и работников медицинских организаций, имеющих высшее медицинское (фармацевтическое) или иное высшее образование, предоставляющих медицинские услуги (обеспечивающих предоставление медицинских услуг) государственной и муниципальной форм собственности по субъектам Российской Федерации за январь-март 2021 года [Электронный ресурс]// Федеральная служба государственной статистики. URL: https://mosstat.gks.ru/folder/64639?print=1 (дата обращения: 02.08.2021).

${ }^{6}$ Там же.
} 
-50-60 градусов описывали словами «дико холодно», «испытал шок». Также респондентам сложно привыкнуть к короткому лету, они отмечают, что им непривычна постоянная влажность воздуха и обилие насекомых (комаров, мошек, слепней). Респондентам как из Тувы, так и из Калмыкии наиболее сложным было привыкнуть к повышенной влажности, особенно в летний период.

Анализ направлений миграции показал, что респонденты как из Калмыкии, так и из Тувы живут и работают и в районах Крайнего Севера и на Дальнем Востоке. Но имеются определенные различия: респонденты из Калмыкии в большинстве своем мигрируют в районы Крайнего Севера, а респонденты из Тувы - на Дальний Восток. Что касается адаптации к климатическим условиям, то особых различий не отмечается.

\section{Жизненные планы трудовых мигрантов}

Для респондентов из Тувы сроки пребывания в регионах трудовой миграции зависят от условий заключенного договора о кадровом обеспечении между прибывшим медицинским работником участником программы и принимающей стороной. Как правило, сроки договоров кадрового обеспечения варьируются от 5 до 10 лет. Максимальный «стаж» миграции у респондентов в момент интервьюирования составил более 6 лет, минимальный - один год.

Подходы к планированию длительности пребывания в регионе миграции у респондентов разные. Первый подход связан с первым сроком договора: респондент ориентируется на точное количество оставшихся лет, в течение которых он выполнит условия договора, и он указывает в ходе интервью, сколько лет еще предстоит проработать в данном регионе (4 года, 6 лет, 2 года и т. д.). Другой подход обусловлен ожиданием наступления определенного жизненного события, например, выхода на пенсию, или полного погашения ранее взятого банковского кредита. Третий подход связан с длительными сроками пребывания - в течение 15-20 лет, которые требуют пролонгации договоров, а также с намерением остаться в регионе трудовой миграции до конца жизни. Как указал один из интервьюируемых, «планирую провести оставшуюся жизнь (в регионе трудовой миграции), если будет работа хорошая и оплата. Охота вернуться к родителям. А так работая здесь, я могу поддержать братьев и сестер, родителей» (женщина, тувинка, 35 лет, Южно-Сахалинск).

Есть те, кто не определился, на сколько лет могут остаться в новом регионе. Такая вариативность указывает на признаки большей открытости, миграционной, трудовой мобильности респондентов, на приобретенные навыки адаптации к иным социокультурным условиям, а также утраты традиционной привязанности к месту рождения и проживания родителей, рода. Об этом свидетельствует и тот факт, что среди участников интервью 5 респондентов (меньшинство) планирует вернуться в Республику Тыва после выполнения условий кадровых договоров, большинство же (18 респондентов) свои дальнейшие жизненные и карьерные планы связывают с переездом в другие регионы России. Причинами, по которым респонденты не планируют возвращаться в Туву, является низкий, по их мнению, уровень оплаты труда в родной республике, который в ближайшее время, по их мнению, не изменится.

Немаловажным является то обстоятельство, что среди респондентов не распространена «вахтовая» форма семьи - большинство респондентов проживают в новом регионе вместе с семьей, а те, кто выехал без членов семьи, планирует их перевезти. Представляется, что семейный характер миграции влияет на длительные горизонты планирования трудовой миграции и на планы переезда в другой регион после завершения сроков договоров.

По результатам интервью, для большинства интервьюируемых (17 респондентов) из Калмыкии срок их нахождения в трудовой миграции зависит от разрешения материальных проблем. Они отмечают, что как только выплатят долги, приобретут недвижимость в Республике Калмыкия, помогут детям с обучением, так сразу уедут назад в Калмыкию или в другой регион с более благоприятным климатом. Две трети опрошенных респондентов (13 респондентов) указали, что хотят заработать «северную пенсию» и получать ее в своем регионе. Для получения «северной пенсии», которая в несколько раз выше, чем в других регионах страны, обязателен стаж не менее 15 лет. В каждом районе имеется свой региональный коэффициент, который значительно увеличивает итоговую сумму пенсионных выплат. Так, средний размер назначенных пенсий в Чукотском автономном округе в 2020 г. составил 25292 руб. (место, занимаемое в Российской Федерации - 1), в Ханты-Мансийском 
автономном округе этот показатель составил 21909 руб., в Ямало-Ненецком автономном округе - 21876 руб. (5 и 6 место соответственно). В Калмыкии средний размер назначенной пенсии один из самых низких в стране, в 2020 г. он составил 12611 руб. (82 место). Республика Тыва по данному показателю занимает 56 позицию, средний размер назначенной пенсии в республике в 2020 г. составил 14040 руб. ${ }^{1}$

Для части респондентов как из Калмыкии, так и Тувы длительность нахождения в трудовой миграции определяется лишь периодом разрешения своих материальных проблем. Профессиональный статус респондентов из Тувы в большинстве случаев определяет длительность их нахождения в трудовой миграции, а именно сроком заключенного договора. Для интервьюируемых из Калмыкии определяющим фактором жизни и работы в районах Крайнего Севера является необходимый трудовой стаж для получения «северной пенсии».

\section{Связи с малой родиной, сохранение этнической, религиозной идентичности в новой (иноэтнической) среде, помощь родственникам}

Интервью показало высокую степень информационной вовлеченности респондентов в события, происходящие в Туве - все без исключения респонденты из Тувы следят за новостями в республике. На сильную эмоциональную связь с малой Родиной выходцев из Тувы указывали авторы ранее проведенных исследований (Ламажаa, 2014: 156). Интернет-коммуникации, соцмедиа позволяют им быть информированными о жизни республики, своего города или поселка, родственников, друзей, коллег. Респонденты отметили, что больше всего их волнуют социальные вопросы: безработица, уровень зарплат, доступность детских садов, школ, работа общественного транспорта, уровень культуры и преступности в республике. Опыт трудовой миграции позволяют опрошенным в негативном ключе сравнивать темпы изменений качества жизни населения в Туве с таковыми в регионах проживания.

Все респонденты из Тувы отметили, что знают о других земляках, которые проживают в месте их нынешнего проживания и трудовой деятельности. За исключением единичных случаев все участники указали на то, что поддерживают общение с представителями своего этнического сообщества.

На вопрос о том, чувствуют ли участники интервью потребность в знании истории и культуры Тувы, половина ответила утвердительно, другая половина - отрицательно. При этом отмечают, что данный вопрос более актуален для их детей, чем для них самих. Особого страха потери этнической идентичности не наблюдается, что объясняется несколькими факторами: потенциально возвратный характер миграции, хоть и пролонгированный во времени - при необходимости каждый из них может вернуться в свою этническую среду - Республику Тыва; наличие этнического сообщества в рассматриваемых локациях миграции, возможность поддерживать общение с выходцами из республики; как показывает социально-демографический состав интервьюируемых. Наблюдается аналогичная ситуация в религиозной сфере: меньшинство имеет в квартирах или домах, где проживают в новом месте буддийский алтарь и читает буддийские молитвы. В свою очередь респонденты отметили, что являются получателями частных отправлений в виде посылок из дома, в которых родные посылают им через автобус традиционные продукты питания, как толченое просо, топленое масло, баранина.

Интервью с калмыками дали нам информацию о наличии активных калмыцких землячеств в поселке городского типа Березово Ханты-Мансийского автономного округа, в г. Анадырь Чукотского автономного округа, в городах Салехарде и Надыме Ямало-Ненецкого автономного округа. В Березово, по оценкам респондентов, проживает более ста калмыков, в Анадыре, считая с поселками, примерно 300 человек. У всех сообществ есть группы в социальных сетях и мессенджерах. Землячества отмечают калмыцкие национальные праздники, Новый год. Многие калмыки, привозят с родины или заказывают оттуда национальные костюмы, элементы национальной одежды или стилизованные платья, жилеты, принимают участие в региональных фестивалях, выставках декоративно-прикладного искусства и др. Некоторые землячества во время религиозных праздников собираются вместе, подключают оборудование и таким образом смотрят или слушают молебны из храмов Калмыкии в прямом эфире.

\footnotetext{
${ }^{1}$ Средний размер назначенных пенсий. Регионы России. Социально-экономические показатели-2020 [Электронный ресурс]// Федеральная службы государственной статистики. URL: https://rosstat.gov.ru/folder/210/ document/13204 (дата обращения: 17.08.2021).
} 
организуют прямые трансляции из храмов Калмыкии. Также по инициативе отдельных земляков проводятся курсы изучения калмыцкого языка, в основном для детей. Помимо общественных мероприятий, большинство также отмечают народные праздники в семьях. У калмыков также есть есть домашние буддийские алтари. Во всех рассматриваемых северных регионах есть возможность получать посылки из Калмыкии особым земляческим каналом. Посылки привозит специальная машина. Передают все: от продуктов до предметов быта. Из продуктов передают мясо (местное мясо практически никто не ест, кроме мяса птицы), колбасы, полуфабрикаты, тушенку калмыцкую.

Модель трудовой миграции, при которой квалифицированные специалисты с высшим и средним профессиональным образованием выезжают в другой российский регион вместе семьей, отличается от той модели, когда уезжает на заработки один из супругов, и его главная социальная, семейная миссия - отправление заработанных средств семье, оставшейся на родине. Специфика рассматриваемой нами модели в том, что респонденты выехали за пределы Республики Тыва не в поисках работы и любого заработка, а в поисках более высокого уровня оплаты труда и дополнительных выплат, предусмотренных в кадровых программах здравоохранения ряда регионов Дальнего Востока и Крайнего Севера. В этом случае финансовые стратегии респондентов, выехавших в эти регионы вместе со своими семьями - обеспечение самих себя, а также финансовые цели, связанные с выполнением кредитных обязательств семьи. Вместе с тем респонденты отмечают, что оказывают финансовую помощь оставшимся жить в Туве родителям, отдельно живущим детям (студентам) и родственникам.

Поскольку большая часть респондентов-калмыков проживает с семьей, то респонденты отмечают, что помогают родственникам только по острой необходимости или по праздникам. Только небольшая часть опрошенных респондентов помогает родственникам в Калмыкии на постоянной основе, но это помощь в основном самым близким - родителям, братьям или сестрам, племянникам.

Результаты проведенных интервью показывают, что благодаря современным средствам связи респонденты включены в информационное пространство своего региона, следят за событиями, происходящими в их республиках, а также помогают оставшимся дома родителям или другим близким родственникам. Особых отличий в стратегиях адаптации у калмыков и тувинцев не выявлено, за исключением того, что коммуникации внутри своего этнического сообщества более ярко выражены у калмыков. Социокультурная самоорганизация внутри сообщества калмыков имеет такие формы взаимодействия, как-то: неформальные встречи, совместное празднование национальных праздников, изучение детьми калмыцкого языка.

\section{Гендерные особенности межрегиональной трудовой миграции}

В гендерной структуре внутренней миграции в России преобладают женщины, причем во всех во всех возрастах, кроме детских (Мкртчян, Флоринская, Казенин, 2020: 22). Как подчеркивают исследователи, такое соотношение оставалось неизменным в течение 2008-2016 гг. (Трубин и др., 2018: 20).

Социально-демографический состав участников глубинного интервью с медицинскими работникам из республики, работающими в регионах Крайнего Севера и Дальнего Востока носит выраженный гендерный характер. Данные исследования социально-экономических процессов в Республике Тыва в 2021 г. также показывают потенциально большую миграционную мобильность женщин республики по сравнению с мужчинами.

В Калмыкии также наблюдается феминизация миграционных потоков разных направлений. Проведенные интервью показали, что респонденты-женщины более адаптивны: многие из них не скучают по малой родине, хорошо интегрируются в местное сообщество. Также считаем важным отметить, что именно женщины были инициаторами миграции, они обращались к родственникам, которые проживали в районах Крайнего Севера с просьбой поиска работы для них или для их мужей, братьев и т. д. Нагляден пример выехавшей семьи трудовых мигрантов из Калмыкии, которые больше 18 лет проживают в Ханты-Мансийском автономном округе: по словам жены (56 лет), ее муж очень сильно скучает по родному поселку, по родным братьям и сестрам, «даже по своей улице скучает». Также из двух взрослых детей, которые заканчивали здесь среднюю школу, высшее образование получили в Тюмени, сын уехал и живет в Калмыкии, но при этом у него нет постоянной работы, дочь вышла замуж и живет в том же поселке, где и родители, профессионально реализована и востребована.

В этой связи можно говорить о ярко выраженной феминизации межрегиональной трудовой миграции из рассматриваемых республик, что совпадает с общероссийским трендом. Такое положение, 
как мы полагаем, обусловлено более высокой социальной мобильностью и экономической активностью женщин на региональном рынке труда в целом.

Таким образом, можно сделать вывод, что женщины не только более мобильны, но и адаптивны к новым условиям жизни и работы.

\section{Заключение}

Исследование показывает, что миграционные модели населения Тувы и Калмыкии складываются как региональные варианты внутрироссийской миграции. Калмыкия и Тува в определенные исторические периоды были регионами-реципиентами, однако в условиях различных социальноэкономических обстоятельств они перестали быть таковыми. В случае как с Тувой, так и с Калмыкией мы наблюдаем переход от статуса реципиента потоков трудовой миграции к статусу донора в последние 15 лет. В Калмыкии активная трудовая миграция населения началась чуть раньше - с конца 1990-х годов.

Интенсивность межрегиональной трудовой миграции зависит не только от показателей экономического развития регионов и ситуации на рынке труда, но и других факторов.

Основной причиной современной пространственной мобильности населения трудоспособного возраста является достаточно серьезные разрывы в региональной дифференциации в доходах и бедности населения, диспропорции на рынках труда.

Миграционная подвижность населения - это живой и естественный процесс, социальная практика, распространенная в современном мире. И в России внутренняя миграция характеризуется все большей открытостью и мобильностью. Для регионов, из которых выбывает трудоспособное население, есть как положительные, так и отрицательные последствия. С точки зрения экономических показателей, как уровень безработицы, уровень бедности населения, выездная трудовая миграция улучшает в какой-то степени социально-экономическую напряженность в регионе. Потери регионовдоноров, особенно, в национальных республиках, связаны с демографией, так как выезжают большей степени лица репродуктивного возраста, а также снижением качества человеческого потенциала, в связи со значительным удельным весом образованного населения среди трудовых мигрантов.

Как было отмечено выше, миграция в данных республиках происходит на фоне разных демографических процессов. В Калмыкии - это депопуляционные процессы, в Туве - это переизбыток трудовых ресурсов. Отток самой активной части населения Калмыкии, а именно молодежи, населения трудоспособного возраста, женщин фертильного возраста, - все это усугубляет демографическую ситуацию в республике.

Существуют также различия в интенсивности миграционных передвижений жителей Тувы и Калмыкии. Население Калмыкии уже несколько десятилетий активно участвует в межрегиональной трудовой миграции по сравнению с интенсивностью миграции тувинцев, что на наш взгляд связано как с территориальной удаленностью Тувы от центральной части страны, которая является основным регионом притяжения мигрантов, так и поздним присоединением к общему социокультурному пространству страны (с 1944 г.) по сравнению с калмыками (1609 г.).

В заключение отметим, что анализ выявил в основном схожие черты миграционного процесса, в который, к сожалению, включается все большее количество населения как из Тувы, так и из Калмыкии. Это в первую очередь экономические обоснования миграции, проблемы социальной адаптации в принимающем социуме с одной стороны и сохранение связи с малой родиной, со своей этнической группой с другой стороны.

Межрегиональная миграционная активность населения Тувы и Калмыкии в ближайшее время будет усиливаться, анализ жизненных стратегий участников интервью, в особенности приобретение жилья в новом месте, указывает на признаки формирования устойчивых этнических диаспор как в больших городах и мегаполисах, так и в регионах Крайнего Севера и Дальнего Востока (в ХантыМансийском, Ямало-Ненецком, Чукотском автономных округах, на о. Сахалин в г. Южно-Сахалинск и др.). 


\section{СПИСОК ЛИТЕРАТУРЫ}

Алешковский, И. А. (2007) Детерминанты внутренней миграции населения в России : автореф. дисс.... к. э. н. M. 28 c.

Анайбан, 3. В. (2020) Современная миграционная ситуация в Республике Тыва // Sciences of Europe. № 49. C. 60-62.

Балакина, Г. Ф., Анайбан, 3. В. (2016) Особенности этнорегиональной миграции в Туве // Социологические исследования. № 10. С. 85-92.

Белоусов, С. С. (2006) Основные тенденции миграционных процессов населения Калмыкии в постсоветский период // Современное состояние и пути развития Юга России. Материалы региональной научной конференции / отв. ред. Г. Г. Матишов. Ростов-на-Дону : Южный научный центр РАН. 517 с. С. 42-44.

История Тувы (2001) / под общей ред. С. И. Вайнштейна и М. Х. Маннай-оола. Новосибирск : Наука. Т. І. 364 с.

Кованова, Е. С., Бадмаева, Н. В., Удаев, Р. А., Алексеев, С. Г. (2019) Этнокультурная безопасность и проблемы сохранения языка в Калмыкии и Бурятии // Oriental Studies. № 12(6). С. 1096-1106. DOI: https://doi.org/10.22162/26190990-2019-46-6-1096-1106

Ламажаа, Ч. К. (2014) Засаянские тувинцы: образ жизни, ценности, идеалы // Новые исследования Тувы. № 3. C. $152-165$.

Мкртчян, Н. В., Флоринская, Ю. Ф., Казенин, К. И. (2020) Внутренняя миграция как ресурс развития России. Социально-экономические эффекты, издержки и ограничения. М. : РАНХИГС. 76 с.

Моллеров, Н. М. (1989) Истоки братства: Русская самоуправляющаяся трудовая колония в Тувинской Народной Республике (1922-1932). Кызыл : Тувинское книжное издательство. 143 с.

Намруева, Л. В. (2011) Влияние миграции молодежи на сохранение этничности (на примере калмыков) // Вестник Российского университета дружбы народов. Серия: Социология. № 2. С. 87-92.

Намруева, Л. В. (2013) Миграционные установки молодежи Калмыкии // Вестник Калмыцкого университета. № 2 (18). С. 64-70.

Николаева, А. И. (1967) Трудовые ресурсы Тувинской АССР и их использование в народном хозяйстве // Ученые записки ТНИИЯлИ. Вып. ХІІ. Кызыл : Тувинское книжное издательство. 219 с. С. 208-220.

Рыбаковский, Л. Л. (2020) Миграция населения: учебное пособие для вузов. М. : Юрайт. 480 с.

Сарыглар, С. А. (2019) Социологический анализ миграционной ситуации в Республике Тыва // Социальная интеграция и развитие этнокультур в евразийском пространстве. Т. 2. № 8. С. 233-238.

Тиникова, Е. Е. (2018) Трансформация городского расселения в национальных республиках Южной Сибири в середине XX - начале XXI века // Новые исследования Тувы. № 4. C. 235-257. DOI: https://doi.org/10.25178/ nit.2018.4.13

Трубин, В., Николаева, Н., Мякишева, С., Хусаинова, А. (2018) Миграция населения в России: тенденции, проблемы и пути решения / Социальный бюллетень. М. : Аналитический центр при Правительстве РФ. 54 с.

Убушаев, М. Б. (2009) Миграционные процессы в республике Калмыкия в постсоветский период // Вестник Калмыцкого института гуманиатрных исследований РАН. № 1. С. 65-69.

Харунова, М. М.-Б., Харунов, Р. Ш. (2021) Особенности формирования городского расселения в Туве в современный период // Новые исследования Тувы. № 3. С. 137-147. DOI: https://doi.org/10.25178/nit.2021.3.11

Хольшина, М. А. (2010) Анализ миграционных процессов в Республике Тыва // Актуальные вопросы экономических наук. № $12-1$. С. 218-222.

Четырова, Л. Б. (2012) Русскоязычие нерусских: истоки и следствия // Mundo Eslavo. № 11. P. 7-19.

Эльдяева, Н. А., Джамбинова, Е. С., Мучкаев, Д. М. (2011) Анализ внутренней трудовой миграции населения региона // Ученые записки Российского государственного социального университета. № 9-2. С. 115-120.

Эльдяева, Н. А., Кованова, Е. С. (2018) Выявление и измерение факторов продолжительности трудовой миграции населения (на примере Республики Калмыкия) // Вопросы статистики. Т. 25. № 7. С. 40-48.

Дата поступления: 31.08.2021 2.

\section{REFERENCES}

Aleshkovskii, I. A. (2007) Determinanty vnutrennei migratsii naseleniia v Rossii [Determinants of internal migration of Russia's population]: Abstract of Diss.... Candidate of Economy. Moscow. 28 p. (In Russ.).

Anaiban, Z. V. (2020) Sovremennaia migratsionnaia situatsiia v Respublike Tyva [Contemporary migration situation in the Republic of Tuva]. Sciences of Europe, no. 49, pp. 60-62. (In Russ.).

Balakina, G. F. and Anaiban, Z. V. (2016) Osobennosti etnoregional'noi migratsii v Tuve [Features of ethno-regional migration in Tuva]. Sotsiologicheskie issledovaniia, no. 10, pp. 85-92. (In Russ.). 
Belousov, S. S. (2006) Osnovnye tendentsii migratsionnykh protsessov naseleniia Kalmykii v postsovetskii period [The main trends of migration of the population of Kalmykia in the Post-Soviet period]. In: Sovremennoe sostoianie i puti razvitiia Iuga Rossii [The current state and ways of developing the South of Russia]. Proceedings of the regional research conference / ed. by G. G. Matishov. Rostov-na-Donu, Iuzhnyi nauchnyi tsentr RAN. 517 p. Pp. 42-44. (In Russ.).

Istoriia Tuvy [The History Of Tuva] (2001) : in 2 vol. 2nd ed / ed. by S. I. Vanshtein and M. Kh. Mannai-ool. Novosibirsk, Nauka. Vol. I. 367 p. (In Russ.).

Kovanova, E. S., Badmaeva, N. V., Udaev, R. A. and Alekseev, S. G. (2019) Etnokul'turnaia bezopasnost' i problemy sokhraneniia iazyka v Kalmykii i Buriatii [Ethnocultural security and problems of language preservation in Kalmykia and Buryatia.]. Oriental Studies, no. 12(6), pp. 1096-1106. (In Russ.). DOI: https://doi.org/10.22162/2619-0990-2019-46-61096-1106

Lamazhaa, Ch. K. (2014) Zasaianskie tuvintsy: obraz zhizni, tsennosti, idealy [Trans-Sayan Tuvans: way of living, values and ideals]. New Research of Tuva, no. 3, pp. 152-165. (In Russ.).

Mkrtchian, N. V., Florinskaia, Yu. F. and Kazenin, K. I. (2020) Vnutrenniaia migratsiia kak resurs razvitiia Rossii. Sotsial'noekonomicheskie effekty, izderzhki i ogranicheniia [Internal migration as a resource for Russia's development: Socio-economic effects, costs and limitations]. Moscow, RANKhIGS. 76 p. (In Russ.).

Mollerov, H. M. (1989) Istoki bratstva. Russkaia samoupravliaiushchaiasia trudovaia koloniia v Tuvinskoi Narodnoi Respublike [The origins of the brotherhood. Russian self-governing labor colony in the Tuvan People's Republic]. Kyzyl, Tuvan book publisher. 144 p. (In Russ.).

Namrueva, L. V. (2011) Vliianie migratsii molodezhi na sokhranenie etnichnosti (na primere kalmykov) [The impact of youth migration on the preservation of ethnicity: the case of Kalmyks)]. Vestnik Rossiiskogo universiteta druzhby narodov. Seriia: Sotsiologiia, no. 2, pp. 87-92. (In Russ.).

Namrueva, L. V. (2013) Migratsionnye ustanovki molodezhi Kalmykii [Migration attitudes of young people of Kalmykia]. Vestnik Kalmytskogo universiteta, no. 2 (18), pp. 64-70. (In Russ.).

Nikolaeva, A. I. (1967) Trudovye resursy Tuvinskoi ASSR i ikh ispol'zovanie v narodnom khoziaistve [Labor resources of the Tuva ASSR and their use in the national economy]. Uchenye zapiski TNIIIaLI. Issue XII. Kyzyl, Tuvan Book Publishing House. 219 p. Pp. 208-220. (In Russ.).

Rybakovskii, L. L. (2020) Migratsiia naseleniia [Population migration]: a textbook for universities. Moscow, Yurait. 480 p. (In Russ.).

Saryglar, S. A. (2019) Sotsiologicheskii analiz migratsionnoi situatsii v Respublike Tyva [Sociological analysis of the migration situation in the Republic of Tuva]. Sotsial'naia integratsiia i razvitie etnokul'tur v evraziiskom prostranstve, vol. 2 , no. 8, pp. 233-238. (In Russ.).

Tinikova, E. E. (2018) Transformatsiia gorodskogo rasseleniia v natsional'nykh respublikakh Iuzhnoi Sibiri v seredine XX - nachale XXI veka [Transformation of urban settlement in the national republics of southern Siberia in the mid-20th to early 21st century]. New Research of Tuva, no. 4, pp. 235-257. (In Russ.). DOI: https://doi.org/10.25178/nit.2018.4.13

Trubin, V., Nikolaeva, N., Miakisheva, S. and Khusainova, A. (2018) Migratsiia naseleniia v Rossii: tendentsii, problemy $i$ puti resheniia [Migration in Russia: trends, problems and solutions]. Moscow, Analiticheskii tsentr pri Pravitel'stve RF. 54 p. (In Russ.).

Ubushaev, M. B. (2009) Migratsionnye protsessy v respublike Kalmykiia v postsovetskii period [Migration processes in the Republic of Kalmykia in the post-Soviet period]. Vestnik Kalmytskogo instituta gumaniatrnykh issledovanii RAN, no. 1, pp. 65-69. (In Russ.).

Kharunova, M. M.-B. and Kharunov, R. Sh. (2021) Osobennosti formirovaniia gorodskogo rasseleniia v Tuve v sovetskii period [Features of urban settlement in Tuva in the Soviet period]. New Research of Tuva, no. 3, pp. 137-147. (In Russ.). DOI: https://www.doi.org/10.25178/nit.2021.3.11

Khol'shina, M. A. (2010) Analiz migratsionnykh protsessov v Respublike Tyva [Analysis of migration processes in the Republic of Tyva]. Aktual'nye voprosy ekonomicheskikh nauk, no. 12-1, pp. 218-222. (In Russ.).

El'diaeva, N. A., Dzhambinova, E. S. and Muchkaev, D. M. (2011) Analiz vnutrennei trudovoi migratsii naseleniia regiona [A study of internal labor migration of the population of the region]. Uchenye zapiski Rossiiskogo gosudarstvennogo sotsial'nogo universiteta, no. 9-2, pp. 115-120. (In Russ.).

El'diaeva, N. A. and Kovanova, E. S. (2018) Vyiavlenie i izmerenie faktorov prodolzhitel'nosti trudovoi migratsii naseleniia (na primere Respubliki Kalmykiia) [Revealing and measuring the factors of the duration of labor migration: the case of the Republic of Kalmykia)]. Voprosy statistiki, vol. 25, no. 7, pp. 40-48. (In Russ.).

Chetyrova, L. B. (2012) Russkoiazychie nerusskikh: istoki i sledstviia [Russian-speaking non-Russians: origins and consequences]. Mundo Eslavo, no. 11, pp. 7-19. (In Russ.).

Submission date: 31.08 .2021$. 